\title{
Withdrawing interferon- $\alpha$ from psychiatric patients: clinical care or unjustifiable stigma?
}

\author{
A. Spennati and C. M. Pariante* \\ Institute of Psychiatry, King's College London, Department of Psychological Medicine, London, UK
}

IFN- $\alpha$ is an effective therapy for chronic viral hepatitis $C$ and today still represents an effective first-line treatment. Unfortunately, its use is associated with a number of side-effects, including psychiatric problems like depression, mania, psychosis, delirium and other cognitive disturbances. Clinicians have been concerned about the risks of worsening of pre-existent psychiatric disorders and of precipitating suicidal attempts in psychiatric patients. The presence of a mental illness is, therefore, often deemed to be a contraindication to the use of antiviral treatment. However, this amounts to stigmatization and discrimination, as it basically implies withholding a life-saving medical treatment because of a psychiatric diagnosis. Is this clinically and socially acceptable? With novel treatments now entering clinical practice as adjuvant to IFN- $\alpha$, it is particularly important to make a statement now, to ensure that psychiatric patients are not left behind. The aim of this editorial is to critically discuss this notion, by reviewing the few studies $(n=14)$ that have indeed administered IFN- $\alpha$ to patients with a pre-existing psychiatric disorder. We find evidence that these patients have rates of treatment adherence and sustained virological response similar to those of non-psychiatric patients, and that their IFN- $\alpha$-induced psychiatric symptoms respond successfully to clinical management. We conclude that there is no support to withdrawing IFN- $\alpha$ therapy from psychiatric patients.

Received 21 February 2012; Revised 12 July 2012; Accepted 17 July 2012; First published online 14 September 2012

Key words: Cytokines, depression, hepatitis $C$, immune, inflammation, interferon- $\alpha$, stigma.

\section{Introduction}

Hepatitis C virus (HCV) infection is a major health problem affecting approximately 170 million people worldwide and 4 million of people in the USA (Asnis \& De La Garza, 2006). Up to $85 \%$ of HCV-infected individuals may develop chronic hepatitis $C$, a disease associated with serious clinical complications, including cirrhosis of the liver and hepatocellular carcinoma. Chronic hepatitis $\mathrm{C}$ is the leading cause of liver transplantation in the developed world. It is estimated that there are approximately 5 million carriers of $\mathrm{HCV}$ in Europe, $70-80 \%$ of whom are likely to develop a chronic infection. In the UK, around 216000 individuals are chronically infected with hepatitis $C$; and, as in all countries, the major risk factor for infection is injecting drug use (HPA, 2011). Therefore, it is easy to understand the importance of using appropriate antiviral treatments to successfully induce a viral remission, in order to reduce the morbidity and mortality associated with chronic hepatitis C.

\footnotetext{
* Address for correspondence: Professor C. M. Pariante, Sections of Perinatal Psychiatry \& Stress, Psychiatry and Immunology, Institute of Psychiatry, Kings College London, Room 2-055, The James Black Centre, 125 Coldharbour Lane, London SE5 9NU, UK.

(Email: carmine.pariante@kcl.ac.uk)
}

First-line treatment consists of a combination therapy with pegylated IFN- $\alpha$ (pegIFN- $\alpha$ ) plus ribavirin. In pegIFN- $\alpha$, polyethylene glycol is added to make IFN- $\alpha$ 's half-life longer, thus allowing once-weekly administration. This combination therapy can reach a sustained viral eradication in $45-95 \%$ of patients, according to viral genotype, viral load and treatment adherence. Novel protease inhibitor antiviral drugs will soon enter clinical care, and promise to increase considerably the rate of viral eradication; but they will be added to IFN- $\alpha$ - not be a substitute for it.

\section{IFN- $\alpha$ neuropsychiatric side-effects}

Unfortunately, the use of IFN- $\alpha$ is associated with numerous side-effects, both medical and neuropsychiatric. Among the first, there are flu-like symptoms, including fever, chills, malaise, tachycardia, headache, arthralgias and myalgias, occurring in more than $30 \%$ of patients, usually at the beginning of the therapy. Neuropsychiatric side-effects are also common, and there are reports of a variety of symptoms, including depressive syndromes, manic and psychotic episodes, and delirium. In a previous review (Quelhas \& Lopes, 2009), prospective studies (that excluded patients with a lifetime history of psychiatric disorders) report an incidence of IFN- $\alpha$-induced 
Table 1. Summary of studies on psychiatric patients taking interferon- $\alpha$

\begin{tabular}{|c|c|c|c|c|}
\hline Study & No. of patients & Diagnosis & IFN- $\alpha$ dose & Outcome of therapy with IFN- $\alpha$ \\
\hline $\begin{array}{l}\text { Dieperink } \\
\text { et al. } 2003\end{array}$ & $\begin{array}{l}55 \text { patients with } \\
\text { hepatitis, of which } \\
42 \text { treated with } \\
\text { IFN- } \alpha \text {. Prospective } \\
\text { study }\end{array}$ & 11 patients with psychiatric diagnosis & $\begin{array}{l}3 \mathrm{MU} \text { of IFN- } \alpha \text { three times/week } \\
\text { and ribavirin } 1000-1200 \mathrm{mg} / \text { day for } \\
24 \text { weeks }\end{array}$ & $\begin{array}{l}\text { Patients with psychiatric diagnosis scored higher on all rating scales at baseline } \\
\text { and became more symptomatic during treatment } \\
\text { Of the } 31(74 \%) \text { patients not in psychiatric care at baseline, } 15(48 \%) \text { required } \\
\text { treatment for neuropsychiatric symptoms, and } 7(23 \%) \text { met criteria for major } \\
\text { depression during INF therapy. The control group of } 13 \text { untreated subjects } \\
\text { showed little change over the } 24 \text {-week period. }\end{array}$ \\
\hline $\begin{array}{l}\text { Dieperink } \\
\text { et al. } 2008\end{array}$ & 16 Prospective study & $\begin{array}{l}16 \text { patients with PTSD, } 5 \text { received IFN, } \\
11 \text { did not receive treatment }\end{array}$ & $\begin{array}{c}1.5 \mu \mathrm{g} / \mathrm{kg} \text { pegIFN- } \alpha-2 \mathrm{~b} \text { once a week } \\
\text { plus ribavirin, for } 12 \text { or } 24 \text { weeks. }\end{array}$ & $\begin{array}{l}\text { Depressive scores significantly increased among the } 5 \text { patients treated with IFN, } \\
\text { but no significant differences in PTSD scores were found compared with } 11 \\
\text { control patients. }\end{array}$ \\
\hline $\begin{array}{l}\text { Evon et al. } \\
2009\end{array}$ & 394 Prospective study & $\begin{array}{l}47 \text { patients with depression according to } \\
\text { CES-D }\end{array}$ & $\begin{array}{l}\text { Combination of pegIFN- } \alpha \text { and } \\
\text { ribavirin }\end{array}$ & $\begin{array}{l}\text { Patients with pre-existent depression were more likely to have psychiatric } \\
\text { adverse events or start new antidepressants }(45 \& v .28 \%) \text { and to have had early } \\
\text { treatment discontinuation ( } 38 \% v .13 \%) \text { Sustained virological response rates } \\
\text { were similar }(38 \% v .40 \% \text { ) to those of participants without baseline depression. }\end{array}$ \\
\hline $\begin{array}{l}\text { Ho et al. } \\
2001\end{array}$ & 33 Retrospective study & $\begin{array}{l}19 \text { patients with previous psychiatric } \\
\text { diagnosis }\end{array}$ & $\begin{array}{l}5 \mathrm{MU} \text { of IFN- } \alpha \text { three times/week for } \\
6 \text { months, followed by a tapering dose } \\
\text { for additional } 6 \text { months }\end{array}$ & $\begin{array}{l}\text { Of the patients with pre-existing psychiatric diagnoses, } 13 / 19(68 \%) \text { developed } \\
\text { major adverse events requiring intervention or discontinuation of therapy } \\
4 / 14(29 \%) \text { patients without psychiatric diagnoses developed major adverse } \\
\text { events } \\
\text { In the psychiatric group, } 6 / 19(32 \%) \text { developed major neuropsychiatric } \\
\text { side-effects compared to } 2 / 14 \text { patients }(14 \%) \text { in the non-psychiatric group } \\
\text { Patients with and without psychiatric diagnoses had equivalent virological } \\
\text { responses to therapy }\end{array}$ \\
\hline $\begin{array}{l}\text { Huckans } \\
\text { et al. } 2010\end{array}$ & $\begin{array}{l}60 \text { Retrospective chart } \\
\text { review }\end{array}$ & 30 patients with schizophrenia, 30 controls & $\begin{array}{l}\text { PegIFN- } \alpha \text {-2a or }-2 \mathrm{~b} \text { or non-pegIFN } \\
\text { for } 24 \text { or } 48 \text { weeks }\end{array}$ & $\begin{array}{l}\text { For all genotypes considered, the patients with schizophrenia were not more } \\
\text { likely than controls to discontinue therapy early for psychiatric symptoms } \\
\text { Patients with schizophrenia seemed to be able to complete and respond to } \\
\text { antiviral therapy for chronic hepatitis } C \text { at rates comparable to those of controls }\end{array}$ \\
\hline $\begin{array}{l}\text { Lang et al. } \\
2010\end{array}$ & 1860 Cohort study & $\begin{array}{l}403 \text { patients with pre-existing psychiatric } \\
\text { disorders }\end{array}$ & $\begin{array}{l}\text { Combination of pegIFN- } \alpha \text { and } \\
\text { ribavirin }\end{array}$ & $\begin{array}{l}\text { Strict adherence was similar in psychiatric and non-psychiatric patients ( } 35 \% v \text {. } \\
39 \% \text { ) as was the rate of sustained virological response }(52 \% v .51 \%) \\
\text { The rate of mental adverse events was higher in psychiatric patients }(78 \% v \text {. } \\
57 \%)\end{array}$ \\
\hline $\begin{array}{l}\text { Lim et al. } \\
2010\end{array}$ & 165 Retrospective study & $\begin{array}{l}33 \text { patients with positive PHQ-9 for mood } \\
\text { disorders, } 132 \text { controls with negative } \\
\text { PHQ }\end{array}$ & $\begin{array}{l}\text { Combination of pegIFN- } \alpha \text { and } \\
\text { ribavirin }\end{array}$ & $\begin{array}{l}41(30 \%) \text { of the control patients had adverse psychiatric events. Psychiatric } \\
\text { events occurred in } 8 \text { ( } 36 \%) \text { of } 22 \text { patients with positive PHQ but negative } \\
\text { MDQ; } 8(73 \%) \text { of } 11 \text { with positive PHQ and positive MDQ had psychiatric } \\
\text { adverse events } \\
\text { The overall sustained viral response rate was } 58 \% \text { and not statistically } \\
\text { significant among groups }\end{array}$ \\
\hline $\begin{array}{l}\text { Mulder } \\
\text { et al. } 2000\end{array}$ & 63 Prospective study & $\begin{array}{l}47 \% \text { of total patients with pre-existing } \\
\text { major depression }\end{array}$ & $\begin{array}{l}3 \mathrm{MU} \text { of IFN- } \alpha \text {, three times a week for } \\
6 \text { months. }\end{array}$ & $\begin{array}{l}\text { No significant rise in psychiatric symptoms among patients on IFN- } \alpha \text { compared } \\
\text { to baseline. A lifetime history of major depression did not predict the onset or } \\
\text { worsening of mood symptoms, although such patients had higher mean } \\
\text { depression scores throughout their treatment. None of the patients made a } \\
\text { suicidal attempt }\end{array}$ \\
\hline
\end{tabular}


(10 MU of IFN- $\alpha$, three times a week for 12 months

\section{Pariante}

et al. 2002

Schaefer

et al. 2003

Schaefer
et al. 2005 Prospective, open
label study

Schaefer

et al. 2007

70 Prospective study

Van Thiel 31 Prospective, open

et al. 1995

label study
25 patients with psychiatric diagnosis, 35 controls

6-10 MU of IFN- $\alpha$ three times a week for 12 months

16 patients with psychiatric disorders, 21 on methadone substitution treatment,

21 former drug users, 23 controls

14 patients with psychiatric illness (group A) treated with citalopram, 11 patients with psychiatric illness, not treated with antidepressant (group B), 11 patients with no psychiatric illness (group C) 22 patients with psychiatric diagnosis (10 with affective disorder, 6 schizophrenia, 6 personality disorder), 17 controls, 18 methadone substitution treatment, 13 former drug users

31 patients with chronic $\mathrm{HCV}$ and psychiatric illness
3 MU of IFN- $\alpha$-2a 3 times weekly plus ribavirin

PegIFN- $\alpha-2 b$ plus ribavirin for 24 weeks IFN- $\alpha-2 \mathrm{a}(180 \mu \mathrm{g} /$ week) plus ribavirin for 24 or 48 weeks
IFN- $\alpha-2 \mathrm{~b}(1.5 \mu \mathrm{g} / \mathrm{kg}$ a week) or
$5 \mathrm{MU}$ of IFN- $\alpha$, three times/week fo 6 months $(n=17)$ or 5 MU daily for 6 months $(n=14)$
$10(41 \%)$ patients in the case group and $10(38 \%)$ patients in the control group interrupted the therapy. However, there was no evidence that psychiatric cases were more likely than controls to interrupt the therapy because of psychiatric adverse effects 11 patients ( 6 cases, 5 controls) developed psychiatric adverse effects (5 major depression, 3 depression not otherwise specified, 1 anxiety disorder, 2 severe dysphoria). 3 patients interrupted the therapy ( 1 case and 2 controls) because of the psychiatric adverse effects After adjusting for the baseline values, there was no evidence that patients with a pre-existing psychiatric diagnosis and patients with no psychiatric diagnosis had different maximal scores on the psychopathological rating scales No significant difference between groups in incidence of psychiatric sideeffects 3 out 25 psychiatric patients required antidepressant treatment during IFN- $\alpha$ therapy. 7 out of 35 controls required antidepressant treatment

No significant differences between groups were detected with respect to IFN- $a$ related development of depression during treatment. No patient in the psychiatric group had to discontinue treatment because of psychiatric deterioration but significantly more of them received antidepressant treatment Sustained virological response was $37 \%$ overall and did not differ significantly between the subgroups

Major depressive symptoms, diagnosed with DSM-IV criteria, developed in $14 \%$ of group A, $64 \%$ of group B and $55 \%$ of group C. IFN- $\alpha$-induced depression in psychiatric risk patients can be improved by use of antidepressant medication

Psychiatric patients were not at increased risk of worsening depression or psychosis during antiviral treatment compared to controls. Taking into account that baseline depression and psychotic symptom scores of those in the psychiatric risk groups were higher than those of the controls, no significant differences were detected during treatment. Sustained virological response was achieved in : $58.6 \%$ of all patients, $58.8 \%$ of controls, $50 \%$ of patients with a psychiatric diagnosis, and $72.2 \%$ of patients on methadone substitution treatment

Only virus genotype was found to significantly influence sustained virological response rate

29 out of 31 patients completed the 6 months therapy. 15 (48\%) patients achieved sustained virological response

Only 4 patients experienced a worsening of the psychiatric symptoms and 2 had to stop the therapy because of that

CESD, Center for Epidemiologic Studies Depression Scale ; IFN, interferon; PHQ, Physician Health Questionnaire ; PTSD, post-traumatic stress disorder ; MDQ, Mood Disorders Questionnaire; MU, million units. 
neuropsychiatric symptoms of $12-41 \%$, while studies without this exclusion criterion report an incidence of $17-58 \%$. Depression appears to be the most common side-effect in patients with chronic hepatitis $C$, and the incidence of major depressive episodes (MDEs), diagnosed according to DSM-IV-TR criteria, generally ranges from $12 \%$ to $42 \%$ (Quelhas \& Lopes, 2009). The incidence of mania during IFN- $\alpha$ treatment is unknown; however, several cases have been reported, including cases of mania emerging spontaneously after IFN- $\alpha$-induced depression and/or after withdrawal of IFN- $\alpha$, and reports of 'switches' from depression to mania during antidepressant therapy (Quelhas \& Lopes, 2009). Cognitive side-effects, especially memory disturbances and concentration problems, have also been found in $10-20 \%$ of patients receiving IFN- $\alpha$, with the risk of cognitive decline possibly being higher with a larger cumulative dose of IFN- $\alpha$ and a longer duration of treatment. There are a few case reports of psychotic episodes induced by IFN- $\alpha$ therapy (Quelhas \& Lopes, 2009).

\section{Worsening of psychiatric symptoms in IFN- $\alpha$ therapy}

Generally, patients with chronic hepatitis $C$ tend to have a significant history of psychopathology (Yovtcheva et al. 2001), which has been considered by some authors as a significant cause for treatment withdrawal, due to the theoretical risk of worsening of psychiatric symptomatology induced by IFN- $\alpha$ treatment. In particular, concerns have been raised about worsening or exacerbation of depression or of suicidal ideation, as well as of psychotic symptoms in patients suffering from bipolar disorder and psychotic illnesses. As recently as in the 2012 Recommendations from the USA National Hepatitis C Program Office, it is prescribed that 'uncontrolled depression or active suicidal ideation is an absolute contraindication to IFN-based therapies' (Yee et al. 2012). While we agree with the accepted clinical practice that patients with active psychopathology should be assessed and supported before starting IFN- $\alpha$, the wording of the recommendation undoubtedly confirms the degree of anxiety by which medical professionals see psychiatric patients in this context. As we have argued already 10 years ago (Pariante et al. 2002), withholding IFN- $\alpha$ inappropriately, especially from members of a stigmatized class, raises questions about fairness and discrimination.

\section{The evidence}

The aim of this editorial is to discuss the existing literature with regard to the administration of IFN- $\alpha$ therapy in patients with chronic hepatitis $C$ and a current psychiatric illness. Studies were identified by using the PubMed database, cross-searching for 'Interferon- $\alpha$ ', 'psychiatric symptoms' and 'chronic hepatitis $C^{\prime}$. Further references were obtained from bibliographies of the reviewed articles. Fourteen studies were considered eligible, and are summarized in Table 1, with details of the findings. Overall, most studies did not find a significantly higher risk of IFN$\alpha$-induced neuropsychiatric toxicity in patients with a psychiatric diagnosis, once the higher baseline psychopathology was taken into account. Interestingly, patients with severe mental illnesses, such as schizophrenia, seem also to be resilient during IFN- $\alpha$. Furthermore, no higher suicidal risk was recorded in these patients. Of particular relevance, and consistently across all studies, is the fact that the rates of completion of therapy and sustained virological response are comparable between psychiatric and nonpsychiatric patients.

\section{Conclusions}

Our analysis of the relatively scant literature highlights that patients with a psychiatric illness have rates of treatment adherence and sustained virological response similar to those of non-psychiatric patients. Moreover, the majority of the studies do not show a significantly higher neurotoxicity of IFN- $\alpha$ therapy in these patients; and even in those studies that find a greater incidence of psychiatric adverse events, psychiatric patients are able to successfully complete the therapy. The lack of an increased risk of suicide in psychiatric patients is also consistent with a recent review on this topic (Sockalingam et al. 2011), which also found that the evidence for an increased suicide risk during IFN- $\alpha$ is largely anecdotal. In most cases, a combination of psychotropic and psychosocial interventions can be used to both prevent worsening of existing symptoms and to manage patients who show a reactivation of psychiatric problems. In fact, there is reasonably good evidence in favour of use of antidepressants, for both prophylaxis and treatment of anxiety and depressive symptoms induced by IFN- $\alpha$ (Baraldi et al. 2012). In addition, the early involvement of a multidisciplinary therapeutic approach, such as the assessment and follow-up with liaison psychiatrists and psychologists (Neri et al. 2010), or an interdisciplinary nurse-managed treatment programme, can be used to support patients with pre-existent psychiatric problems undergoing IFN- $\alpha$ therapy (Gardenier et al. 2011). It should be noted that it is important not to underestimate the fact that patients with no psychiatric history have virtually the same risk of developing IFN- $\alpha$-induced side-effects, and as 
such they may suffer even more from the lack of management programmes and prophylactic strategies. In summary, while we support the notion of assertive psychosocial and pharmacological prevention in these patients, we find no evidence that patients with a pre-existing psychiatric disorder should not be treated with interferon- $\alpha$; and withdrawal of such treatment should be considered as discrimination.

\section{Acknowledgements}

This paper received funding from The NIHR 'Biomedical Research Centre for Mental Health', Institute of Psychiatry and South London and Maudsley NHS Foundation Trust and the Commission of European Communities 7th Framework Programme Collaborative Project Grant Agreement no. 22963 (Mood Inflame).

\section{Declaration of Interest}

None.

\section{References}

Asnis GM, De La Garza R (2006). Interferon-induced depression in chronic hepatitis $C$ : a review of its prevalence, risk factors, biology and treatment approaches. Journal of Clinical Gastroenterology 40, 322-335.

Baraldi S, Hepgul N, Mondelli V, Pariante CM (2012). Symptomatic treatment of interferon- $\alpha$-induced depression in hepatitis C: a systematic review. Journal of Clinical Psychopharmacology 32, 531-543.

Dieperink E, Ho SB, Thuras P, Willenbring ML (2003). A prospective study of neuropsychiatric symptoms associated with interferon-alpha- $2 \mathrm{~b}$ and ribavirin therapy for patients with chronic hepatitis C. Psychosomatics 44, 104-112.

Dieperink E, Leskela J, Dieperink ME, Evans B, Thuras P, Ho SB (2008). The effect of pegylated interferon-alpha2b and ribavirin on posttraumatic stress disorder symptoms. Psychosomatics 49, 225-229.

Evon DM, Ramcharran D, Belle SH, Terrault NA, Fontana RJ, Fried MW (2009). Virahep-C Study Group. Prospective analysis of depression during peginterferon and ribavirin therapy of chronic hepatitis C: results of the Virahep-C study. American Journal of Gastroenterology 104, 2949-2958.

Gardenier D, Wisnivesky J, McGinn LK, Kronish IM, McGinn TG (2011). Hepatitis C treatment completion in individuals with psychiatric comorbidity and depression. Gastroenterology Nursing 34, 102-106.

Ho SB, Nguyen H, Tetrick LL, Opitz GA, Basara ML, Dieperink E (2001). Influence of psychiatric diagnoses on interferon-alpha treatment for chronic hepatitis $\mathrm{C}$ in a veteran population. American Journal of Gastroenterology 96, 157-164.
HPA (2011). Hepatitis C in the UK, Report. Health Protection Agency, London.

Huckans M, Mitchell A, Ruimy S, Loftis J, Hauser P (2010). Antiviral therapy completion and response rates among hepatitis $C$ patients with and without schizophrenia. Schizophrenia Bulletin 36, 165-172.

Lang JP, Melin P, Ouzan D, Rotily M, Fontanges T, Marcellin P, Chousterman M, Cacoub P; CheObs Study Group (2010). Pegylated interferon-alpha2b plus ribavirin therapy in patients with hepatitis $C$ and psychiatric disorders: results of a cohort study. Antiviral Therapy 15, 599-606.

Lim C, Olson J, Zaman A, Phelps J, Ingram KD (2010). Prevalence and impact of manic traits in depressed patients initiating interferon therapy for chronic hepatitis $C$ infection. Journal of Clinical Gastroenterology 44, 141-146.

Mulder RT, Ang M, Chapman B, Ross A, Stevens IF, Edgar C (2000). Interferon treatment is not associated with a worsening of psychiatric symptoms in patients with hepatitis C. Journal of Gastroenterology and Hepatology 15, 300-303.

Neri S, Bertino G, Petralia A, Giancarlo C, Rizzotto A, Calvagno GS, Mauceri B, Abate G, Boemi P, Di Pino A, Ignaccolo L, Vadala' G, Misseri M, Maiorca D, Mastrosimone G, Judica A, Palermo F (2010). A multidisciplinary therapeutic approach for reducing the risk of psychiatric side-effects in patients with chronic hepatitis $C$ treated with pegylated Interferon alpha and ribavirin. Journal of Clinical Gastroenterology 44, 210-217.

Pariante CM, Landau S, Carpiniello B ; Cagliari Group (2002). Interferon alpha-induced adverse effects in patients with a psychiatric diagnosis. New England Journal of Medicine 347, 148-149.

Pariante CM, Orrù MG, Baita A, Farci MG, Carpiniello B (1999). Treatment with interferon alpha in patients with chronic hepatitis and mood or anxiety disorders. Lancet 354, 131-132.

Quelhas R, Lopes A (2009). Psychiatric problems in patients infected with hepatitis $C$ before and during antiviral treatment with interferon-alpha: a review. Journal of Psychiatric Practice 15, 262-281.

Schaefer M, Hinzpeter A, Mohmand A, Janssen G, Pich M, Schwaiger M, Sarkar R, Friebe A, Heinz A, Kluschke M, Ziemer M, Gutsche J, Weich V, Halangk J, Berg T (2007). Hepatitis $C$ treatment in 'difficult-to-treat' psychiatric patients with pegylated interferon-alpha and ribavirin: response and psychiatric side effects. Hepatology 46, 991-998.

Schaefer M, Schmidt F, Folwaczny C, Lorenz R, Martin G, Schindlbeck N, Heldwein W, Soyka M, Grunze H, Koenig A, Loeschke K (2003). Adherence and mental side-effects during hepatitis $\mathrm{C}$ treatment with interferon alpha and ribavirin in psychiatric risk groups. Hepatology 37, 443-451.

Schaefer M, Schwaiger M, Garkisch AS, Pich M, Hinzpeter A, Uebelhack R, Heinz A, van Boemmel F, Berg T (2005). Prevention of interferon-alpha associated depression in psychiatric risk patients with chronic hepatitis C. Journal of Hepatology 42, 793-798. 
Sockalingam S, Links PS, Abbey SE (2011). Suicide risk in hepatitis $C$ and during interferon-alpha therapy: a review and clinical update. Journal of Viral Hepatitis 18, 153-160.

Van Thiel DH, Friedlander L, Molloy PJ, Fagiuoli S, Kania RJ, Caraceni P (1995). Interferon-alpha can be used successfully in patients with hepatitis $C$ virus-positive chronic hepatitis who have a psychiatric illness. European Journal of Gastroenterology and Hepatology 7, 165-168.

Yee HS, Chang MF, Pocha C, Lim J, Ross D, Morgan TR, Monto A; Department of Veterans Affairs Hepatitis C
Resource Center Program; National Hepatitis C Program Office (2012). Update on the management and treatment of hepatitis $C$ virus infection: recommendations from the Department of Veterans Affairs Hepatitis C Resource Center Program and the National Hepatitis C Program Office. American Journal of Gastroenterology 107, 669-689.

Yovtcheva SP, Rifai MA, Moles JK, Van Der Linden BJ (2001). Psychiatric comorbidity among hepatitis-C-positive patients. Psychosomatics 42, 411-415. 